\title{
Reclamación por venta de perro de distinta raza, vicios ocultos y otros. Comentario a la Sentencia de la Audiencia Provincial de Barcelona, Sección 16ạ, de 9 de abril de 2013
}

\section{Carmen Navarro Villanueva ${ }^{1}$}

\section{SUCINTA EXPOSICIÓN DE LOS HECHOS}

Los hechos que dan origen a la sentencia de la AP de Barcelona, Sección 16ā de 9 de abril de $2013^{2}$, que revoca parcialmente la Sentencia del Juzgado de Primera Instancia de Barcelona nํ23, de 30 de septiembre de 2011 y que, seguidamente se comentará, son los siguientes: La demandante (y después recurrente) compró en la tienda de la demandada (absuelta en primera instancia) una perra, a la que llamó Menta, de raza, presuntamente, caniche toy. A fin de compensar la diferencia de valor entre un caniche toy y un caniche enano, la actora reclamaba 250 euros. Ello no obstante, el Juzgado de Primera Instancia consideró irrelevante, desde la perspectiva del incumplimiento del contrato de compraventa, que la perra adquirida fuera de raza distinta.

Por otra parte, aducía la demandante que, en las semanas siguientes a la compra, Menta tuvo que ser atendida de diversas patologías leves (tos, otitis, presencia del parásito toxicara canis, diarreas). Y, ya más adelante, la perra padeció una dermatitis atópica y diversos problemas de visión, razón por la cual fue intervenida en dos ocasiones de cataratas (aproximadamente al año y año medio de su venta, respectivamente). A tal efecto, la compradora (ahora recurrente) reclamaba $3.452,05$ euros, esto es, el coste de las operaciones quirúrgicas. Ello no obstante, la sentencia de primera instancia, que se recurre, no considera probado ni la presencia en Menta

\footnotetext{
${ }^{1}$ Profesora titular de Derecho Procesal de la Universidad Autónoma de Barcelona.

2 http://www.derechoanimal.info/bbdd/Documentos/1099.pdf
} 
de parásitos o de alergias en la fecha de venta ni el carácter hereditario de la afección oftalmológica.

Ya en otro orden de cuestiones, la propietaria de Menta ponía de relieve, en primera instancia, la omisión por parte de la vendedora de la obligación de inscribir a Menta en el LOE ${ }^{3}$. Por ello, la reclamación indemnizatoria, en concepto de daño moral, de 1500 euros, venía, parcialmente fundada, en tal omisión. Sin embargo, tal extremo fue desestimado en primera instancia dado que el Juzgado consideró que era responsabilidad, en este caso concreto, de la compradora la falta de inscripción del animal.

Finalmente, la sentencia de primera instancia considera intrascendente, a efectos de conferir validez al contrato de compraventa, la observancia o no en el mismo de las prescripciones contenidas en la ordenanza municipal reguladora de la tenencia y venta de animales de diciembre de $2003^{4}$.

\section{CONTENIDO DE LA RESOLUCIÓN DEL RECURSO DE APELACIÓN}

Así las cosas, la compradora de Menta, cuya demanda de juicio verbal reclamando la cuantía de 5.202,05 euros en concepto de resarcimiento por los perjuicios patrimoniales sufridos a causa de las carencias que presentaba la perra, fue íntegramente desestimada en primera instancia, interpuso recurso de apelación ante la Audiencia Provincial de Barcelona. Dicho recurso, resuelto por un solo Magistrado al amparo del art. 82.2.1 LOPJ, da lugar a la Sentencia de la AP de Barcelona, Sección 16a , de 9 de abril de 2013, que paso a comentar.

\footnotetext{
${ }^{3}$ EL Libro de Orígenes Español (L.O.E.) es gestionado por la Real Sociedad Canina de España (R.S.C.E.) y tiene como fines, entre otros, hacer un seguimiento a la genealogía de todos los perros de raza inscritos en el mismo, estimular su conservación y mejora genética, y proporcionar información a los agentes interesados.

${ }^{4}$ http://www.derechoanimal.info/bbdd/Documentos/479.pdf . A la fecha de publicación de este Comentario, la Ordenanza de Barcelona se encuentra en proceso de modificación: http://www.derechoanimal.info/esp/page/3100/modificacion-de-la-ordenanza-municipal-de-barcelona
} 


\subsection{Compensación económica a la compradora que adquiere un animal de raza} distinta a la acordada

La recurrente aduce, como primer argumento de su recurso de apelación, que el perro que compró resultó de una raza distinta a la convenida. Al respecto, la AP de Barcelona considera probado, en virtud de la prueba pericial practicada, que la entrega fue, en efecto, de un animal de raza distinta y de menor valor. En efecto, un certificado particular emitido por una veterinaria, refrendado después en el juicio, aseguraba que las medidas de Menta (32 cm en cruz) eran superiores al estándar de raza caniche toy, que no supera los 28 centímetros $^{5}$. Por consiguiente, admite este primer motivo de apelación y condena a pagar a la parte recurrida (vendedora) la "moderada consecuencia resarcitoria (250 euros) postulada por la propietaria demandante habida cuenta que las razas más pequeñas se pagan más que las grandes", según afirmara en el proceso una de las veterinarias.

\subsection{El principio dispositivo impide en el caso resuelto por la sentencia analizada la resolución del contrato de compraventa o la rebaja del precio de compra}

El siguiente extremo analizado por la sentencia es el relativo a quién debía hacerse cargo de los gastos originados por las diversas patologías leves que sufrió el animal adquirido. A tal efecto, el Magistrado considera que la naturaleza común de tales afecciones impide inferir la concurrencia de un supuesto de incumplimiento esencial por parte de la vendedora o de un hipotético vicio oculto.

La perra sufrió, también, según quedó acreditado de la prueba de testigos-peritos practicada, una dermatitis atópica y diversos problemas de visión, razón por la cual hubo de ser operada en dos ocasiones de cataratas. A los efectos que aquí interesan, es preciso poner de relieve, siguiendo la resolución comentada, que tales patologías, al ser de base genética, tampoco suponen un incumplimiento grave del vendedor. En este sentido, el Magistrado apunta que si acaso aquellas patologías, que ocasionaron sendas intervenciones, podrían constituir vicios o defectos ocultos determinantes de la resolución de la venta o de la rebaja proporcional. Y es que, en el contrato de compraventa, suscrito entre la recurrente y la demandada absuelta, figuraba una clausula

\footnotetext{
${ }^{5}$ En el juicio celebrado en primera instancia, por cierto, se aportó informe de un veterinario que acreditaba que la perra era de raza caniche toy, fruto del cruce de dos ejemplares de caniche toy inscritos en el Libro de Orígenes Español.
} 
conforme a la cual, en caso que la perra padeciese algún "defecto oculto de carácter hereditario aparecido dentro del año siguiente a la venta", la compradora tendría derecho a reclamar de la tienda de animales la sustitución del caniche por otro de idénticas características y precio. Sin embargo, la actora (compradora) no ejercitó tales pretensiones en el proceso, de manera que, en virtud del principio dispositivo que rige en nuestro proceso civil, el juez no puede tenerlas en cuenta.

Llegados a este punto, conviene detenernos al objeto de recordar que el principio dispositivo que rige nuestro proceso civil, entre otras manifestaciones, comprende aquélla a tenor de la cual corresponde a las partes fijar los términos del debate, esto es, el objeto del juicio (art. 412.1 LEC) ${ }^{6}$. Asimismo, el principio dispositivo significa que las resoluciones judiciales serán congruentes con las pretensiones de las partes. Consecuentemente, la Audiencia Provincial no podía ni resolver la venta ni aplicar una rebaja al precio pagado por Menta puesto que la actora en ningún momento formuló tales pretensiones sino que se limitó a solicitar el resarcimiento del daño patrimonial que las deficiencias del animal le habían irrogado.

\subsection{La obligación de saneamiento de vicios o defectos ocultos en los animales}

En otro orden de cuestiones, es preciso señalar que la cláusula convenida entre las partes acerca de la sustitución de la perra o de la rebaja proporcional del precio, encuentra su razón de ser en las previsiones establecidas en nuestro Código Civil acerca del saneamiento de la cosa objeto de la venta. Efectivamente, entre las obligaciones del vendedor figura, a tenor de lo dispuesto en el art. 1461 CC, el saneamiento, de manera que el vendedor debe responder de los vicios o defectos que tuviera la cosa vendida. En esta misma línea, el art. 1485 del mismo Texto Legal

\footnotetext{
${ }^{6}$ Sobre el principio dispositivo, vid. ampliamente, BERZOSA FRANCOS, Principios del proceso civil en “Justicia” 1992, III, pp. 553-620; GOMEZ DE LIAÑO, En torno al principio dispositivo en el proceso en “RGLJ”, 1973; VAZQUEZ SOTELO, Lo principios del proceso civil, en “Justicia”, 1993, III-IV, p. 599 y ss. El principio dispositivo, como "principio inspirador del proceso civil", en palabras de MONTERO AROCA, Introducción al derecho procesal, Tecnos, 1976, p. 228, confiere a las partes la posibilidad de acudir o no al proceso, la de acudir a la jurisdicción ordinaria o a la arbitral, la de fijar los términos del debate y la de disponer libremente del proceso (desistiendo el actor del proceso o renunciando a la acción, allanándose el demandado a la demanda, llegando actor y demandado a una transacción, etc).
} 
dispone que el vendedor responde de los vicios o defectos ocultos que tuviera la cosa vendida, aunque los ignorase ${ }^{7}$. De todos modos, en este caso concreto, conviene reiterar que la actora no ejercita la acción específicamente prevista en el contrato para la reparación de los defectos ocultos manifestados en forma de patologías de naturaleza hereditaria, esto es, no pedía ni la resolución del contrato de compraventa ni la rebaja proporcional del precio sino que se limitaba a reclamar la cantidad desembolsada para curar a Menta, razón por la cual el Magistrado no podía, so pena de vulnerar el principio dispositivo, acordar la resolución de la venta o una rebaja en el precio.

El saneamiento por vicios ocultos del animal que ha sido objeto de una compraventa, al que se dedican, con carácter específico, los arts. 1491 a 1499 CC, da lugar a pronunciamientos harto variados en nuestra jurisprudencia puesto que, en definitiva, la cuestión clave reside en la prueba de si tales vicios ocultos existían con anterioridad a la venta o si hay alguna suerte de responsabilidad en el comprador. Así, por ejemplo, según la reciente Sentencia de la Audiencia Provincial de Badajoz de 27 de junio de 2013, el recurrente (en su día comprador de unas novillas) no consigue probar que sus animales quedaran contaminados a raíz de la compra al vendedor de unas novillas, por lo que el vendedor fue absuelto ${ }^{8}$. En este mismo sentido, la Sentencia de la Audiencia Provincial de Madrid, Sección 10å , de 25 de octubre de 2011, afirma que no se produce un incumplimiento sustancial de las obligaciones contractuales ya que se trataba de una enfermedad contraída con posterioridad a la compra, de modo que el vendedor

\footnotetext{
${ }^{7}$ En este sentido, la Sentencia de la Audiencia Provincial de Huelva de 30 de mayo de 2012 (http://www.derechoanimal.info/bbdd/Documentos/1373.pdf) recuerda que el conocimiento de los vicios ocultos por parte del vendedor no es preciso puesto que no se requiere un dolo específico para que el transmitente responda civilmente. En su virtud, confirma en términos taxativos la sentencia condenatoria dictada en primera instancia contra el vendedor de un caballo que padecía una grave enfermedad.

${ }^{8}$ En el caso resuelto por la resolución citada en el texto, Sentencia de la Audiencia Provincial de Badajoz de 27 de junio de 2013 (http://www.derechoanimal.info/bbdd/Documentos/1374.pdf), al parecer fue el propio comprador el que realizó una mezcla de animales "del todo punto inadmisible desde la perspectiva de la buena llevanza de la explotación ganadera que exigía poner en cuarentena a las reses compradas y, posteriormente a las objeto de posible contagio".
} 
cumplió con sus obligaciones y no se apreció en el animal vicios o defectos existentes con anterioridad a su transmisión ${ }^{9}$. Por el contrario, en el caso resuelto por la Sentencia de la Audiencia Provincial de Segovia de 30 de septiembre de $2011^{10}$ queda acreditado en el juicio que las novillas padecían caquexia con carácter previo a la venta, enfermedad que no surge de manera repentina sino tras varios días de deficientes cuidados y alimentación y, en consecuencia, se confirma la sentencia absolutoria dictada a favor del comprador, que recibió las reses afectadas de aquella grave patología.

\subsection{Reconocimiento del daño moral}

Como último extremo del recurso, la recurrente reclamaba una indemnización en concepto de daño moral, dado que la perra que compró no figuraba inscrita en el LOE. Según la resolución comentada, la publicidad de la tienda de animales en la que la recurrente compró a Menta parece, por una parte, sugerir que todos los animales que

9 Sentencia de la Audiencia Provincial de Madrid, Sección 10a, de 25 de octubre de 2011: http://www.derechoanimal.info/bbdd/Documentos/1375.pdf. En términos similares, la Sentencia de la Audiencia Provincial de Murcia de 1 de octubre de 2009 (http://www.derechoanimal.info/bbdd/Documentos/1376.pdf) confirma la sentencia absolutoria dictada a favor del demandado (vendedor) puesto que el comprador no aportó ningún informe pericial que concretara si las patologías causantes de la muerte del loro existían o no con anterioridad y si eran, en su caso, detectables mientras que el vendedor sí presentó al proceso un informe pericial, emitido 20 días después de la venta, que afirmaba el excelente estado de salud del loro. Desde otra perspectiva, el caso resuelto por la citada sentencia es interesante puesto que recuerda la vigencia del art. 1497 CC, conforme al cual, "si el animal muriese a los tres días de comprado, será responsable el vendedor, siempre que la enfermedad que ocasionó la muerte existiera antes del contrato, a juicio de los facultativos”. Tal disposición no era aplicable al caso, dado que el loro había muerto de hepatitis al cabo de un mes de la compra pero el tribunal se plantea la posible existencia de vicios o defectos ocultos en el animal objeto de la compraventa, que pudieran hacer surgir una eventual responsabilidad del vendedor al amparo del 1495 CC, acción que puede ser ejercitada dentro de los cuarenta días (art. 1496 CC) con resultado también negativo, según hemos visto.

${ }^{10}$ http://www.derechoanimal.info/bbdd/Documentos/1377.pdf 
vende están inscritos en el $\mathrm{LOE}^{11}$. Y, sin embargo, por otra parte, en el contrato de garantía se preveía una doble vía para llevar a cabo la inscripción, en función de que el formulario de identificación canina, a rellenar para su tramitación, se entregase junto con el cachorro o en fechas posteriores. Ahora bien, la sentencia de la AP de Barcelona comentada, considera que no hay prueba de la entrega de dicho formulario a la recurrente, de manera que, aplicando las reglas de la carga de la prueba, el Magistrado concluye que debe imputarse a la vendedora la falta de inscripción de Menta. En efecto, como es sabido, la carga de la prueba en el proceso civil significa que corresponde a las partes la aportación de los medios de prueba que apoyen sus respectivas pretensiones. Ahora bien, como explica ARMENTA DEU, el no ejercicio del derecho a aportar medios de prueba, "no provoca sanción ni responsabilidad, pero sí acarrea consecuencias desfavorables" ${ }^{\prime 12}$.

Así, si una vez llegado el momento de dictar sentencia, el Juez considera que determinados hechos son dudosos, deberá determinar a quién correspondía probarlos y, en consecuencia, a quién perjudica la falta de prueba sobre los mismos. En el caso que nos ocupa, de acuerdo con las reglas de la carga de la prueba, incumbía a la vendedora probar el hecho positivo de la fecha de entrega del formulario, conforme a lo dispuesto en el art.217.3 LEC $^{13}$. Por tal razón, la sentencia acoge el motivo alegado por la recurrente y concluye que la incertidumbre de la compradora acerca de la inscripción de Menta en el LOE generó "el estado de inquietud y zozobra que funda toda reclamación de daño moral, que en el presente caso se cifrará en otros 250 euros

\footnotetext{
${ }^{11}$ La publicidad de la tienda de animales señalaba: “Tots els exemplars s'inscriuen en el LOE de la Reial Societat Canina d'Espanya” (“Todos los ejemplares se inscriben en el LOE de la Real Sociedad Canina de España").

${ }^{12}$ Vid. al respecto, ARMENTA DEU, Lecciones de Derecho Procesal Civil, 5a ed., Marcial Pons, Madrid, 2010, p. 172.

${ }^{13}$ A tenor de lo dispuesto en el art. 217.3 LEC, "Incumbe al demandado o al actor reconvenido la carga de probar los hechos que, conforme a las normas que les sean aplicables, impidan, extingan o enerven la eficacia jurídica de los hechos a que se refiere el apartado anterior", esto es, corresponde al demandado probar aquellos hechos que impidan, extingan o enerven la eficacia jurídica de los hechos alegados por el demandante en su demanda.
} 
dA derecho ANIMAL la web center de los animales con derecho

habida cuenta las coordenadas cuantitativas de la operación (el precio de compra del caniche no alcanzó los mil euros"). 